\title{
Features of the design and construction of pre- trial detention centers in Russia, taking into account environmental standards
}

\author{
I $V$ Karavaev $^{1, *}, A N$ Kimachev $^{1}, V V$ Prokudin $^{1}, S N$ Suharev $^{1}, S N$ Matulis ${ }^{2}$ \\ ${ }^{1}$ Academy of the Federal penitentiary service of Russia, 1 Sennaya str., Ryazan, 390000, Russia \\ ${ }^{2}$ Institute of Legislation and Comparative Law under the Government of the Russian Federation, \\ Cheremushkinskaya str., 34, Moscow, 117218, Russia
}

\begin{abstract}
Pre-trial detention of persons accused of committing a criminal offense is an integral measure in the justice system of any state. In most countries, there are specialized institutions for maintenance of this category of citizens. In Russia, they are called pre-trial detention centers. Such institutions belong to the penitentiary systems. By isolating a potential offender, pre-trial detention centers perform several tasks: 1) exclude the possibility of persons to hide from the investigation and the court; 2) make it impossible for them to continue criminal activities; 3) maximally complicate their obstruction of establishment of truth in a criminal case. Implementation of these tasks is facilitated to the maximum extent by proper design and construction of pre-trial detention centers, competent placement of facilities, security buildings and premises, optimal use of special gratings, doors and locks. The article deals with the regulation of design and construction standards of pre-trial detention centers by Russian legislation. The authors analyze the experience of penitentiary systems of foreign states, as well as the norms in force in Russia, highlighting strengths and weaknesses. The actual double subordination is established in solving the current problem. On the one hand, the department executing the preliminary report, on the other, the department organizing and controlling design and construction of institutions executing preventive measure. Such inconsistency creates problems in practical application of provisions of existing norms, leads to errors and, as a result, inadequate performance of isolation of suspects and accused of committing crimes. Based on the results of the study, it was proposed to create a unified legal document regulating the procedure for design and construction of pre-trial detention centers. There is a need to exclude the listed issues from provisions of documents not related to design and construction sphere. This will provide proper, common understanding of existing problems and their faster resolution.
\end{abstract}

\section{Introduction}

The most important functions of proper design of detention facilities are:

\footnotetext{
${ }^{*}$ Corresponding author: a.copytowa@yandex.ru
} 
1. Ensuring continuous surveillance:

- of behavior of suspects, accused and convicted persons in order to prevent and suppress their of crimes;

- of territory of pre-trial detention centers and territories immediately adjacent to them.

2. Implementation:

- of access control between isolated areas, zones;

- of control over the movement of prisoners;

- of checking the presence of prisoners;

- of control over the serviceability of the fences of restricted areas of the institution;

- of control over the observance of the established order of relationship by prisoners and personnel.

3. Ensuring the established order of detention by persons in custody.

The Federal Penitentiary Service of Russia (hereinafter - the FPS) is carrying out a set of measures aimed at bringing the conditions of detention of suspects and accused in accordance with the requirements of legislation of Russian Federation. One of these areas is the creation of additional places to accommodate suspects, accused and convicted persons. The number of pre-trial detention centers and places in them for accommodation of persons suspected and accused of committing crimes is given in Fig. 1 and Fig. 2 [7].

\section{The number of pre-trial detention centers in Russia}

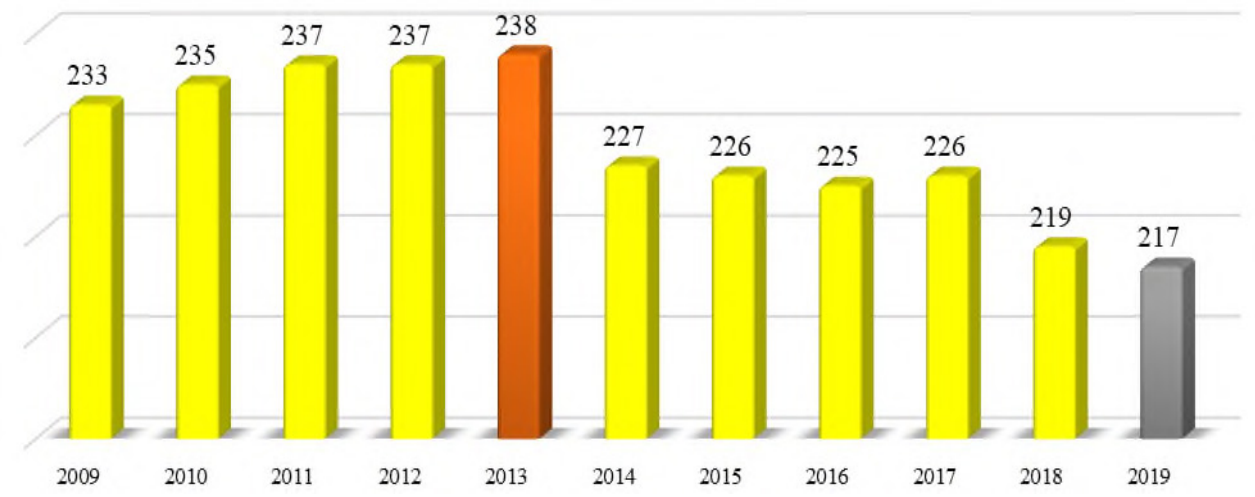

Fig. 1. The number of pre-trial detention centers in Russia.

So, during the period of the federal target program "Development of Penitentiary System (2007-2016)", 14 pre-trial detention centers and 33 security buildings with a total filling limit of 14,156 places were built (reconstructed): 5 with 2,180 places and 2 security buildings with 1,300 places meet international standards ( 7 square meters per person).

The construction and commissioning of another 5 and 4 regime buildings with a total filling limit of 7601 seats was completed: 4 with 6000 places (Chuvash RepublicChuvashia, Sverdlovsk and Voronezh regions, St. Petersburg) and 2 regime buildings with 647 places (Vladimir region and Moscow) comply with international standards (7 square meters per person).

The federal target program "Development of Penitentiary System (2017-2025)" is currently in force, which includes measures for construction (reconstruction) of 11 pre-trial detention centers and 15 security buildings with a total capacity of 15075 places. 


\section{The number of places for suspects and accused ones in pre-trial detention centers in Russia}

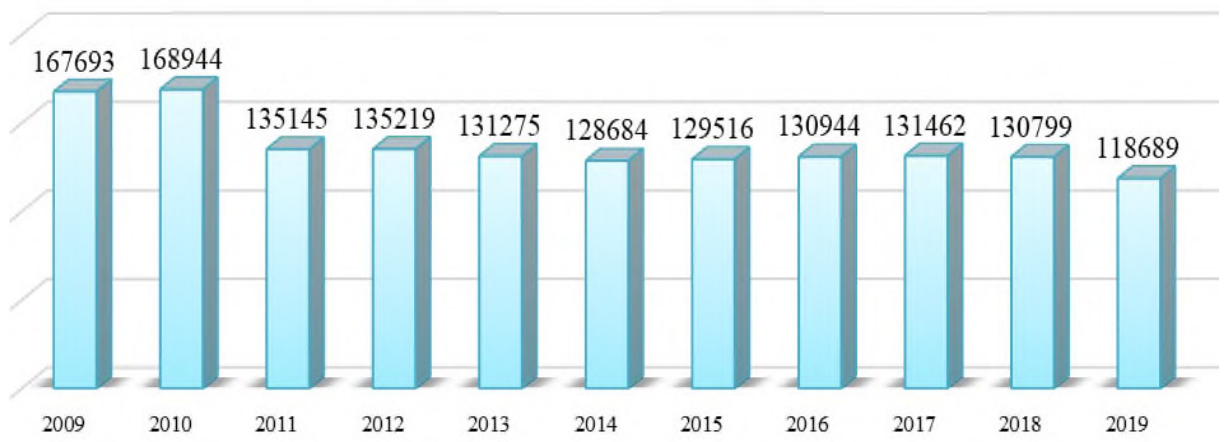

Fig. 2. The number of places for suspects and accused ones in pre-trial detention centers in Russia.

Reconstruction and construction of pre-trial detention centers and security buildings is carried out according to outdated standards. Requirements of normative acts, according to which this work is carried out, have morally outlived themselves and do not correspond to modern realities.

The object of the study includes the organizational and legal relations arising in connection with the proper equipment of pre-trial detention centers of penal system of Russian Federation. The subject of the study includes the regulatory legal acts of Russian Federation (federal laws and departmental regulations of the Ministry of Justice of Russian Federation) governing design of pre-trial detention centers; experience of foreign penitentiary systems. states in the area under consideration, as well as the law enforcement practice of remand prisons of the Federal Penitentiary Service of Russia.

The purpose of the study is to develop proposals for improving legal regulation in this area on the basis of studying and understanding the requirements of regulations governing the equipment of pre-trial detention centers, analyzing the current state of solving issues of designing places of preliminary detention in Russia and in foreign countries.

In this regard, the main tasks of the work are:

- study of issues of legal regulation of equipment in pre-trial detention centers in Russia;

- analysis of international experience in design, construction and equipment of prisontype institutions;

- study of general requirements for the equipment of pre-trial detention centers;

- identifying the issues of equipping security rooms in pre-trial detention centers;

- proposal of ways to solve the identified problems, changes in the current legislation.

\section{Research literature review and research methodology}

The issues of legal regulation of design and construction of Russian institutions of penal system and pre-trial detention centers, in particular, have not been sufficiently studied. There are only a few works in this area. All of them, in one way or another, are connected with the period when in Russia they wanted to convert correctional institutions from colonies into prisons. Among these are the works of O.A. Alfimova. and R.V. Andriyanov, who researched the issues of innovative construction technologies and new equipment for domestic prisons (Novokuznetsk, 2012) [1]; I. V. Karavaeva created a textbook, but only from an educational point of view, she considered the issues of equipping pre-trial 
detention centers (Ryazan, 2012) [6]; Bochkareva V.V. researched the issues of improving the use of engineering and technical means in correctional facilities (Moscow, 2016) [3]; Useeva R.Z. studied design of penitentiary institutions from the point of view of their fortification (Moscow, 2015) [8]. Against the general background, a team of authors from the Research Institute of Federal Penitentiary Service should be highlighted, who conducted several studies and touched upon the issues of architecture, construction and equipment of foreign prisons, potentialities of its use, as well as advanced domestic experience in the construction of new generation prisons (Moscow, 2011,2012 ) $[2,4,5]$.

In the process of carrying out this research, several general scientific and special scientific methods of cognition were consistently applied. At the initial stage of the study, when assessing the development of Russian legislation on the regulation of design and construction of institutions executing a preventive measure in the form of imprisonment, the historical and systemic-structural methods of scientific knowledge were used.

At the second stage of studying the practice of foreign countries in design and construction of places of preliminary detention, the comparative legal method was applied. This made it possible to compare similar provisions of Russian legislation with the content of the legislation of individual foreign countries in the area under consideration.

At the third, final stage, in the study of specifics of regulation of design and construction of pre-trial detention centers in Russia, the dialectical method of cognition was used. The same method, along with the inductive and deductive methods of formal logic, was used to determine the ultimate goals of improving the requirements for design and construction of pre-trial detention centers in Russia, the feasibility of changing the provisions of current legislation in the field under study.

\section{Results}

The study has shown that there is no unified approach to the regulation of design and construction of pre-trial detention centers in modern Russian legislation. Requirements for design and construction are "scattered" in the legal documents of different departments. On the one hand, this is the Ministry of Justice and the Federal Service for the Execution of Punishments as a department directly implementing the preventive measure in the form of detention. On the other hand, the Ministry of Construction and Housing and Communal Services of Russian Federation, as a department organizing and controlling design and construction process, develops standards in this area. Requirements developed by different departments do not take into account each other's requests. Undoubtedly, existing double subordination in many respects complicates the process of correct solution of issues of design and construction of pre-trial detention centers.

\section{Discussion}

The modern design of pre-trial detention facilities of Federal Penitentiary Service of Russian Federation is regulated by a number of regulations of various levels. Each of them touches on its own layer of issues and is important that cannot be overestimated. Let's consider the main documents regulating the equipment of pre-trial detention centers in Russia.

For a more in-depth study of the issues of legal regulation of design and construction of pre-trial detention centers [6], we will conditionally divide all documents concerning the equipment of pre-trial detention centers into two groups: regulations specially created to regulate issues of equipment of detention centers and regulations containing certain norms 
concerning equipment. So, the following should be attributed to the normative acts specially created to regulate the issues of equipment of pre-trial detention centers:

1. Set of rules. Pre-trial detention centers of the penal system. Design Rules / Order of the Ministry of Construction, Housing and Utilities of Russian Federation No. 245 / pr dated April 15, 2016 (SP 247.1325800.2016);

2. Catalog "Special (security) products for the equipment of pre-trial detention centers, prisons, correctional and specialized institutions of Federal Penitentiary Service of Russian Federation / order of the Federal Penitentiary Service of Russian Federation dated July 26, 2007 No. 407;

3. Manual on equipping with engineering and technical means of protection and supervision of objects of penal system / order of the Ministry of Justice of Russian Federation dated September 4, 2006 No. 279;

The listed normative acts are fundamental in the construction and equipment of pre-trial detention centers in Russia. Let's consider them in more detail.

Central to the hierarchy of equipment-related documents is the Set of Rules. Pre-trial detention facilities of penal system. Design rules / order of the Ministry of Construction and Housing and Communal Services of Russian Federation of April 15, 2016 No. 245 / pr (SP 247.1325800.2016). It fixes all the nuances of construction, equipment, standards and requirements, placement of a pre-trial detention center on the territory of buildings and structures. Thus, the Order covers following issues: indicators of the number of staff, composition and indicators of the capacity of pre-trial detention centers; structures of pretrial detention centers, general solutions of buildings and complexes; requirements for land plots and placement of buildings; composition and area of the premises of buildings of the local, security and storage zone of the investigation isolation wards requirements for the location and equipment of premises; requirements for special products (doorways; window openings; security products; general construction and design requirements); engineering equipment; engineering and technical means of protection; radio systems, clocks, cable TV, city telephone communications, local area networks; fire safety requirements; environmental protection.

The second most important, in our opinion, special normative act regulating the equipment of pre-trial detention centers is the Order of Federal Penitentiary Service of Russian Federation dated July 26, 2007 No. 407, approving the "Catalog" of Special (security) products for the equipment of pre-trial detention centers, prisons, correctional and specialized institutions of the Federal Penitentiary Service of Russian Federation".

The catalog lists high-performance products and their technical characteristics. So, the catalog contains a description of:

1) Protective structures (reinforced doors; chamber doors; reinforced hatches; manholes; fire doors; bullet-resistant doors; lattice doors; window lattices; chamber lattices; mechanism for window closing; special lattices; lattice partitions; window shutters; transmission windows; protective fences; bulletproof window and armored sections; turnstiles of the checkpoint passage corridor);

2) Equipment of premises for keeping suspects, accused and convicts (cell beds; special purpose beds; punishment cells; cell tables; cell benches; chairs; bedside tables; stands; shelves; cabinets; hangers);

3) Equipment of special (security) rooms (key catchers; lattice partitions dividing; tables for cleaning weapons; tables for search; cabinets for weapons and special equipment; cabinets for documents; dressing cabinets; hangers; key cabinets; guard cabinets).

Undoubtedly, the listed special departmental acts regulate a fairly wide range of issues related to design and construction of pre-trial detention centers, however, some aspects are reflected in other regulatory documents. 
So, for example, Federal Law No. 103-FZ of July 15, 1995 "On detention of suspects and accused of committing crimes" in Article 23 (Material and household support) touches on equipment issues, stating that suspects and accused are provided with an individual sleeping place, all cameras are provided with radio broadcasting, and, if possible, televisions, refrigerators and ventilation equipment. The Law also establishes that the sanitary area in a cell for one person should not be less than four square meters.

Legislators according to Art. 16 of the Federal Law "On Detention of Suspects and Accused of Crimes" do not include equipment in the maintenance of internal order, however, Internal Regulations of Investigation Areas of the Penitentiary System, approved by Order of the Ministry of Justice of Russian Federation dated October 14, 2005 No. 189, also affect the regulation equipment of some objects of pre-trial detention centers. So, for example, paragraph 42 establishes a list of items with which the cells of pre-trial detention centers are equipped, and paragraph 136 also concerns the equipment of exercise yards.

Another example of regulation of design of pre-trial detention centers by non-special acts is the normative act governing the organization of service for ensuring supervision in pre-trial detention centers and prisons of the penal system of Russian Federation. Initially, this normative act covers the issues of supervision (control over the behavior of persons held in pre-trial detention centers), however, its text also contains provisions on design and equipment. So, for example, it establishes requirements for design of an attendant's room, a room for storing special equipment, equipping the premises of the head of the corps department and the post-employee who supervises the cameras, designing the premises of checkpoint, requirements for the premises of CCTV system operators.

In addition, a number of annexes of the document in question describe various premises, and the description concerns, including their equipment: punishment cells, cells for temporary isolation of suspects, accused and convicts who have had a nervous breakdown, exercise yards, rooms for telephone conversations, rooms for conducting short-term dates.

Undoubtedly, departmental acts cannot regulate general requirements for construction, design, etc. These issues are the prerogative of State Standards, Sanitary and Epidemiological Rules and Regulations, building codes and regulations that must be followed during the construction and equipment of pre-trial detention centers.

A pre-trial detention center is a very complex and versatile facility. On the territory of a pre-trial detention center, there should be objects of various purposes, both of a purely security nature and of a domestic, general social nature, but at the same time, providing for special elements that ensure the established regime of detention, as well as the execution and serving of sentences in the form of imprisonment. The territory is designed taking into account zoning of the entire area of the complex. The territory is conventionally divided into local, security and economic-storage zones [1].

In the local zone, administrative buildings are located: an administrative building and a checkpoint. In the restricted zone, there are buildings for security and service purposes. In turn, the structure of the economic and warehouse zone includes: a checkpoint; warehouses; ancillary workshops; garage; town for keeping service dogs. The location of buildings and structures of local, restricted zones relative to each other, as a rule, is taken in accordance with the approximate schemes of master plans.

Penitentiary architecture is one of the most important elements in the organization and management of any penitentiary system. It must meet the requirements of the regime, the safety of prisoners and correctional staff, hygiene requirements and serve as a means of correcting criminals. Implementation of the goals and objectives of penitentiary legislation, observance of the rights and legitimate interests of persons serving sentences largely depends on the architecture of buildings of the prison.

The principle of centralization is the main principle of prison construction of any penitentiary system. It requires that all prison buildings and premises be compactly located 
around the center, that is, a central structure from which they are clearly visible and from where it is easy for prison staff to enter them, if necessary.

The construction of prison-type institutions is primarily aimed at performing a specific function - isolating suspects, accused and convicted persons [8]. That is why the architectural typology of prisons is usually based on two criteria: 1) the category of prisoners (prisons for adults and minors, military prisons, psychiatric prisons); 2) the type of detention regime (high security prisons, medium security prisons, low security prisons) [5].

It is known from the history of penitentiary architecture that the first and, perhaps, the most famous systems of detention were the so-called Pennsylvania and Oborny systems of organizing the serving of sentences in the form of imprisonment. Both of these systems developed in the late 18 th and early 19 th centuries. The overwhelming majority of modern European prisons still have exactly this layout of the detention system. A distinctive feature of these systems is the shape of the modal enclosures. They are designed in the form of a "fan", "star", "cross" or "semicircle". In all such institutions, long corridors are organized with cameras located on one or both sides [7].

In a number of countries (for example, Sweden, Belgium) construction of so-called "bunker" prisons is used. On the territory of the institutions, a kind of "prisons in prisons" designed for 70-100 places are being designed. They are intended for especially dangerous categories of prisoners first of all, for those prone to escape. Such "prisons within prisons" are separated from the outside world by concrete walls and fences with barbed wire through which current is passed, as well as a system of locks. Such institutions are equipped with individual cells with a shower and toilet with an area of 12 square meters (in ordinary prisons the standard size of cells for one person is 6.5 meters) $[9,10]$.

The prisons in Japan and other Asian states, with the exception of China, which are distinguished by a rather tough regime for keeping prisoners, are built according to the Pennsylvanian principle: they almost always consist of solitary cells in fanning out or cruciform buildings. In China, on the contrary, the principle of construction of prisons differs from the European ones in the low-rise prison buildings (no more than two floors - it is easier to bring the special contingent to work) and the powerful security system, which provides for a high fence around the perimeter and a triple wire fence. There are practically no single and small cells in Chinese prisons [4].

San Vittore Prison (Milan, Italy), built in 1879: a steep facade overlooking the sea, the rest of the buildings fan out from the central building. The prison is designed to hold 800 prisoners in solitary confinement cells of 10 square meters. Another example of this type is the German prison Moabit, which has opened in 1844 and is still in operation. It consists of five buildings converging in the common center, where the central observation post is located. The ray-shaped bodies form a fan-like shape. Each building, three stories high, consists of single cells [3]. The chambers are illuminated by wall windows, in the door of each of them there is an opening window for the transfer of food and an opening for observation. Common wards are located near solitary confinement cells in the prison.

\section{Conclusion}

Summing up, we came to the following conclusions:

Great attention is paid to the construction and equipment of prisons, in the broad sense of the word, in all countries. The equipment of penitentiary institutions is one of the most important elements of the organization of the regime. World practice follows the path that prison equipment is aimed at ensuring the safety of prisoners and staff, and meeting hygiene requirements. After all, construction and equipment is the starting point for a proper regime, implementation of the goals and objectives of the penitentiary legislation, 
observance of the rights and legitimate interests of persons serving sentences largely depends on the competent equipment of buildings and premises of the prison.

The overwhelming majority of prisons in the world are built on the principle of centralization, when all prison buildings, structures and premises inside them were compactly located around the center, that is, a central structure, from which they are clearly visible and from where it is easy for prison staff to enter them, if necessary. There is no centralization principle in Russia. The security buildings of pre-trial detention centers are usually designed in a rectangular shape. On each floor, cameras can be located both on one side of the corridor, and on both.

The prison architecture in most countries of the world is based on the principle of low number of storeys. Among existing prisons, multi-storey buildings with various types of supervision are rare. Cruciform or star-shaped prisons use linear or indirect surveillance of prisoners; in prisons with a semicircular structure, direct observation is used (in those places that do not fall into the direct vision zone, constant video recording is carried out). In Russia, in spite of the requirement to build security buildings of pre-trial detention centers no higher than three floors, there are five, six and even seven-story versions.

All prison settings represent a compromise between safety and cost. Maximum security facilities require more sophisticated security systems and high staff-to-prisoner ratios. The main purpose of isolating prisoners in them is to prevent escapes, therefore, more expensive building materials and equipment are used in their construction, which will be difficult to disrupt or disassemble, for example, masonry, concrete and steel. Increased security requirements lead to higher costs associated with building, maintaining and operating maximum security prisons. Practice shows that safety and costs are usually inversely proportional to each other, more safety and control - more costs (both for construction and operation), and vice versa.

In Russia, in fact, there is a double regulatory subordination in solving the problems of design and construction of pre-trial detention centers. On the one hand, there are norms of the Ministry of Justice and the Federal Penitentiary Service, on the other, the Ministry of Construction and Housing and Communal Services. As a result, such a two-polar dependence leads to the incomplete solution of the tasks facing the pre-trial detention centers: 1) exclude the possibility of persons to escape from the investigation and the court; 2) make it impossible for them to continue to engage in criminal activity; 3) maximally complicate their obstruction of establishment of the truth in a criminal case.

Based on the results of the study, we propose to create a unified legal document regulating the procedure for design and construction of pre-trial detention centers. Such a document should be developed jointly by the Ministry of Justice and the Ministry of Construction, Housing and Communal Services. It is advisable to exclude the listed issues from the provisions of regulatory enactments that are not related to design and construction (departmental instructions in the field of supervision and security, Internal Regulations, etc.). This will provide a proper, common understanding of existing problems and a more universal and faster solution.

\section{References}

1. O.A. Alfimova, R.V. Andriyanov, Bulletin of the Kuzbass Institute 11, 17-23 (2012)

2. Architecture, construction and equipment of foreign prisons (Conclusions from the review of foreign experience) (Research Institute of the Federal Penitentiary Service of Russian Federation, Moscow, 2012)

3. V.V. Bochkarev, Actual problems of Russian law 4(65), 168-175 (2016) 
4. Foreign prisons: features of architecture, construction and equipment (Research Institute of the Federal Penitentiary Service of Russian Federation, Moscow, 2011)

5. The use of innovative technologies for construction of prisons: an analytical review with proposals on the potentiality of using foreign and advanced domestic experience in the construction of a new generation of prisons when carrying out work on the conversion of existing institutions into institutions of a new type (Research Institute of the Federal Penitentiary Service of Russian Federation, Moscow, 2012)

6. I.V. Karavaev, Equipment of pre-trial detention centers: a textbook Library of the UIS employee Ryazan (Academy of the Federal Penitentiary Service of Russia, 2012)

7. L.O. Pichugina, T.V. Zalatina, A.I. Gatina, Scientific Almanac 11-3(13), 351-355 (2015)

8. R.Z. Useev, Bulletin of the penal system 10(161), 19-22 (2015)

9. M.G. Gorodnichev, K.A. Dzhabrailov, K.A. Polyantseva, R.A. Gematudinov, Systems of Signals Generating and Processing in the Field of on Board Communications 9078616 (2020) doi:10.1109/ieeeconf48371.2020.9078616

10. K. Dzhabrailov, M. Gorodnichev, R. Gematudinov, M. Chantieva, Advances in Intelligent Systems and Computing 1116, 354-364 (2020) doi:10.1007/978-3-03037919-3_35 